\title{
Pit-1/GHF-1 and GH expression in the MCF-7 human breast adenocarcinoma cell line
}

\author{
C Gil-Puig, M Blanco ${ }^{1}$, T García-Caballero ${ }^{1}$, C Segura $^{1}$ and \\ R Pérez-Fernández
}

Department of Physiology, School of Medicine, University of Santiago de Compostela, 15782 Santiago de Compostela, Spain

${ }^{1}$ Department of Morphological Sciences, School of Medicine, University of Santiago de Compostela, 15782 Santiago de Compostela, Spain

(Requests for offprints should be addressed to R Pérez-Fernández, Departamento de Fisiología, Facultad de Medicina, Universidad de Santiago de Compostela, 15782 Santiago de Compostela, Spain; Email: fsropefe@usc.es)

\begin{abstract}
GH expression in mammary tumors has been related to the increase and spreading of cell proliferation. Using the MCF-7 human breast adenocarcinoma cell line, it has been demonstrated that autocrine GH-stimulated mammary carcinoma cell proliferation decreased the apoptosis rate and enhanced cell spreading. Surprisingly, no data are available about the presence of Pit-1 (the main pituitary regulator of $\mathrm{GH}$ ) or $\mathrm{GH}$ expression in this cell line.
\end{abstract}

Using RT-PCR, Western blot and immunohistochemistry, we have demonstrated the presence of both mRNA coding Pit-1 and $\mathrm{GH}$ as well as Pit-1 and GH protein in the MCF-7 cell line. These data could imply that Pit-1 may be an adequate target to inhibit breast cell proliferation.

Journal of Endocrinology (2002) 173, 161-167

\section{Introduction}

Breast cancer is the most common malignancy, accounting for $31 \%$ of all cancers in women. It is known that human breast cancer cells secrete a number of growth factors and cytokines that can be involved in the control and spreading of breast cancer cell proliferation. In recent years, the role of pituitary hormones, namely prolactin and growth hormone $(\mathrm{GH})$, in the pathogenesis of human breast cancer has received considerable attention. Although the presence of $\mathrm{GH}$ receptor has been reported, it is not known whether $\mathrm{GH}$ and Pit-1 gene expression is present in human breast cancer cell lines.

Pit-1/GH factor-1 (GHF-1) is a pituitary-specific transcription factor that includes in its structure a homeodomain characteristic of a superfamily of developmental regulatory proteins (Bodner et al. 1988, Ingraham et al. 1988). The presence of an additional domain, conserved in Pit-1 and the proteins OCT-1, OCT-2 and UNC-86 gave rise to the term POU domain which characterizes this family of homeodomain proteins (Rosenfeld 1991). Pit-1 plays an essential role both for cell differentiation during organogenesis of the anterior pituitary in mammals (Simmons et al. 1990, Castrillo et al. 1991) and as a transcriptional activator for pituitary gene transcription (Lefevre et al. 1987, Nelson et al. 1988). Pit-1, in co-ordinate action with additional factors, is responsible for the specification, expansion and survival of three specific cell types: somatotropes, lactotropes and a subset of thyrotropes, during anterior pituitary development ( $\mathrm{Li}$ et al. 1990, Lin et al. 1994), as well as for the transcriptional regulation of target promoters (i.e. GH, prolactin, $\beta$-subunit of thyrotropin (TSH), GH-releasing hormone receptor genes and its own gene) (Lefevre et al. 1987, Nelson et al. 1988, Chen et al. 1990, Li et al. 1990, McCormick et al. 1990, Lin et al. 1992, 1994). Mice with inactivating mutations or deletions of the Pit-1 gene fail to generate somatotropes, lactotropes and thyrotropes and consequently exhibit anterior pituitary hypoplasia and dwarfism (Li et al. 1990), demonstrating the importance of Pit-1 in the ontogeny of the pituitary gland. Expression of Pit-1 transcripts and protein is highly regulated, and the presence of Pit-1 protein is correlated both temporally and spatially with activation of the GH gene during pituitary development (Dollé et al. 1990).

Thus, at the pituitary level, Pit-1 is absolutely necessary as a transcription factor to pituitary GH gene expression, but GH gene transcription is also present in extrapituitary tissues (i.e. mammary glands). The presence of $\mathrm{GH}$ mRNA in the mammary gland of the cat, dog and human (Mol et al. 1995a,b) has been demonstrated. GH receptor mRNA is present in both human breast cancer cell lines and tissues (Sobrier et al. 1993, Decouvelaere et al. 1995) and both the mRNA and the $\mathrm{GH}$ receptor protein were demonstrated in the human normal and neoplasic breast (Mertani et al. 1998). Moreover, some authors have found 
elevated GH levels in sera as well as increased plasma insulin-like growth factor (IGF) levels in patients with breast cancer, suggesting a possible relationship between GH/IGF-I and breast cancer (Emerman et al. 1985, Peyrat et al. 1993).

However, the role of Pit-1 on GH expression in non-pituitary tissues is unclear. Pit-1 and GH coexpression in human placenta (Bamberger et al. 1995, Schanke et al. 1997), in hemopoietic and lymphoid tissues as well as in HL-60 and RAJI leukemic cells (Delhase et al. 1993a) has been demonstrated, suggesting that, like the pituitary, Pit-1 controls GH gene expression. On the contrary, in canine normal mammary tissues, no detectable Pit-1 mRNA was found despite the presence of GH gene transcripts before and after treatment with progestins. Interestingly, GH-expressing mammary tumors showed Pit-1 expression (Lantinga-van Leeuwen et al. 1999).

The human breast adenocarcinoma cell line MCF-7 has been used to study how autocrine $\mathrm{GH}$ increases the rate of mammary carcinoma cell spread and cell proliferation and transcriptional activation (Kaulsay et al. 1999, 2000). However, the expression of Pit-1 as well as GH in the MCF-7 cell line has not been previously reported. For this reason, and in order to clarify the mechanisms involved in these GH-Pit-1-mammary tumor relationships, we have investigated the presence of Pit-1 and GH expression in the MCF-7 cell line using RT-PCR, Western blot and immunohistochemistry.

\section{Materials and Methods}

\section{Cell culture and RNA isolation}

MCF-7 human breast adenocarcinoma cell line was obtained from the European collection of cell cultures (Salisbury, Wilts, UK). Stock culture was grown in $90 \mathrm{~mm}$ Petri dishes using Dulbecco's modified essential medium (DMEM) supplemented with 10\% fetal bovine serum, 100 $\mathrm{U} / \mathrm{ml}$ penicillin, $100 \mu \mathrm{g} / \mathrm{ml}$ streptomycin and $2 \mathrm{mM}$ L-glutamine in an air-carbon dioxide (95:5) atmosphere at $37^{\circ} \mathrm{C}$. Confluent cells were washed twice with phosphate-buffered saline (PBS) and harvested by a brief incubation with a trypsin-EDTA solution (Sigma, St Louis, MO, USA) in PBS. Total RNA isolation was performed with TRIzol reagent (Gibco-BRL, Life Technologies, Grand Island, NY, USA). Briefly, total RNA was extracted with chloroform $(0.2 \mathrm{ml} / \mathrm{ml}$ homogenate), precipitated with isopropanol, washed with $75 \%$ ethanol, and dissolved in diethylpyrocarbonatetreated, Rnase-free water. RNA concentration and purity were determined by absorbance.

\section{RT-PCR analysis}

cDNA synthesis was generated under the following conditions: $2 \mu \mathrm{g}$ total RNA was incubated for $50 \mathrm{~min}$ at $37^{\circ} \mathrm{C}, 15 \mathrm{~min}$ at $42{ }^{\circ} \mathrm{C}$ and $5 \mathrm{~min}$ at $95^{\circ} \mathrm{C}$ with 400 units M-MLV reverse transcriptase (Gibco-BRL) in the buffer (50 mM Tris-HCl, pH 8.3, $50 \mathrm{mM} \mathrm{KCl,} 10 \mathrm{mM} \mathrm{MgCl}$, $10 \mathrm{mM}$ dithiothreitol and $0.5 \mathrm{mM}$ spermidine) with $2 \mathrm{mM}$ of each deoxynucleotide triphosphate, 20 units RNase inhibitor (RNasin RNase inhibitor; Promega, Madison, WI, USA) and $500 \mathrm{ng}$ random primers (Promega) in a total volume of $40 \mu \mathrm{l}$.

Six microliters of the cDNA generated under the above-mentioned conditions were amplified by PCR using 2 units Taq polymerase (Promega) in a buffer containing $50 \mathrm{mM} \mathrm{KCl}, 10 \mathrm{mM}$ Tris- $\mathrm{HCl}(\mathrm{pH} 9 \cdot 0), 0 \cdot 1 \%$ Triton X-100 and $1.5 \mathrm{mM} \mathrm{MgCl}_{2}$, with $0.2 \mathrm{mM}$ of each deoxynucleotide triphosphate and $25 \mathrm{pM}$ each of two oligonucleotide primers, to a total volume of $50 \mu \mathrm{l}$. The samples were denatured at $94{ }^{\circ} \mathrm{C}$ for $1 \mathrm{~min}$, annealed at $53{ }^{\circ} \mathrm{C}$ or $60^{\circ} \mathrm{C}$ for 1 min (Pit-1 and GH respectively) and extended at $72{ }^{\circ} \mathrm{C}$ for $1 \mathrm{~min}$, for 35 cycles, with an extension step for $10 \mathrm{~min}$ at $72{ }^{\circ} \mathrm{C}$ in the last cycle. The amplified product was separated by electrophoresis on a $2 \%$ agarose gel and visualized by ethidium bromide staining and ultraviolet transillumination. Each experiment was carried out at least three times, with similar data being obtained in each of them.

\section{Primer sequences}

Primer sequences for Pit-1 PCR amplification were as follows: primer A (5'-GCAACTCTGCCTCTGATA ATG-3') was a 21 mer corresponding to nucleotides 186-206 in exon 1 of Pit-1 cDNA and primer B (5'CCACCAATTTACTTTTCCGCC-3') was an antisense 21 mer corresponding to nucleotides $460-480$ in the third exon of Pit-1 cDNA. The PCR product obtained is $295 \mathrm{bp}$ in length. Primer sequences for GH PCR amplification were as follows: primer A (5'-CCGACAC CCTCCAACAGGGA-3') was a 20 mer corresponding to nucleotides 314-334 in the third exon of GH cDNA and primer B (5'-CCTTGTCCATGTCCTTCCTG-3') was a 20 mer corresponding to nucleotides $638-658$ in the fifth exon of GH cDNA. The PCR product obtained is $344 \mathrm{bp}$ in length.

\section{Western blot analysis}

MCF-7 cells were lysed at $4{ }^{\circ} \mathrm{C}$ in $1 \mathrm{ml}$ lysis buffer (50 mM HEPES, pH 7.5, $150 \mathrm{mM} \mathrm{NaCl}, 5 \mathrm{mM}$ EGTA, $1.5 \mathrm{mM} \mathrm{MgCl}_{2}, 1 \%$ SDS, $10 \%$ glycerol, 1\% Triton $\mathrm{X}-100,10 \mathrm{mM}$ sodium orthovanadate, $4 \mathrm{mM}$ phenylmethylsulfonyl fluoride and $50 \mu \mathrm{g} / \mathrm{ml}$ aprotinin) and sonicated. Cell lysate was then centrifuged at $14000 \mathrm{~g}$ for 5 min at $4{ }^{\circ} \mathrm{C}$ and the resulting supernatant was collected, and protein concentration was determined by the Bradford method. Pit-1 and GH were then immunoprecipitated with a monoclonal anti-Pit-1 antibody (Transduction laboratories, Lexington, KY, USA) or a monoclonal 


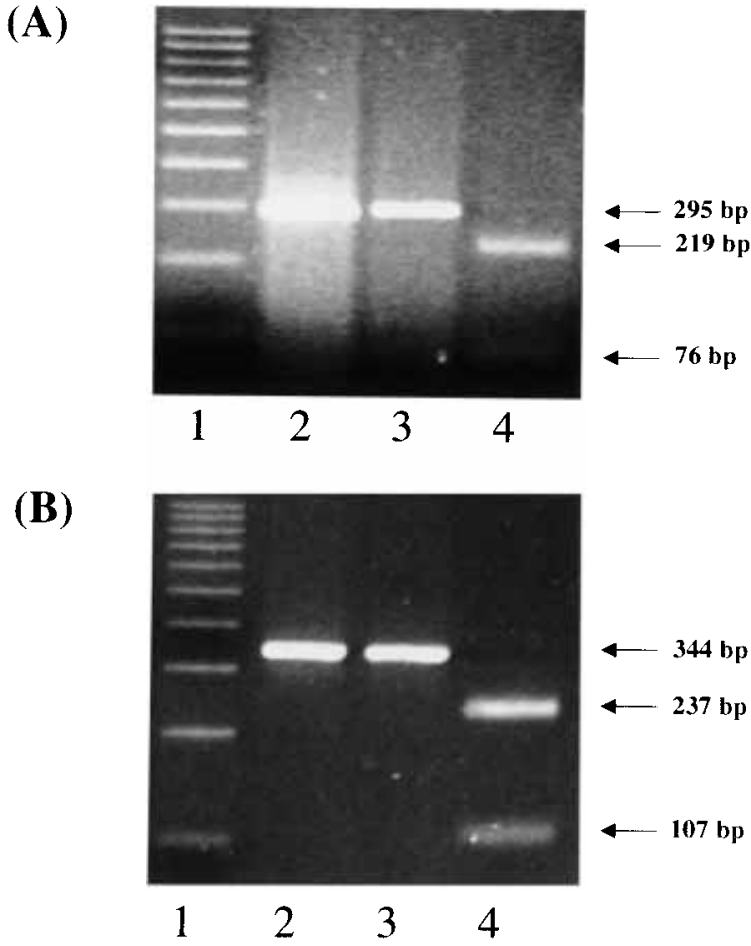

Figure 1 Detection of Pit- 1 and GH mRNA in MCF-7 human breast adenocarcinoma cell line. mRNA from the MCF-7 cell line was used a template for CDNA synthesis and then amplified by PCR using specific primers for Pit-1 and GH. (A) Ethidium bromide staining of PCR product corresponding to the Pit-1 cDNA. Lane 1: molecular weight marker (1000 bp DNA ladder). Lane 2: RT-PCR product from human pituitary used as control. Lane 3: uncleaved RT-PCR product from the MCF-7 cell line. Lane 4: RT-PCR product from the MCF-7 cell line cleaved with Mbo II. (B) Ethidium bromide staining of PCR product corresponding to the GH mRNA. Lanes 1, 2 and 3: as above in (A). Lane 4: RT-PCR product cleaved with Bgl II.

anti-human $\mathrm{GH}(\mathrm{hGH})$ antibody (Sorin, Italy) and incubated overnight at $4{ }^{\circ} \mathrm{C}$. Protein-G-Sepharose $(30 \mu \mathrm{l})$ was then added and incubated for $45 \mathrm{~min}$. The samples were centrifuged at $14000 \mathrm{~g}$ for $3 \mathrm{~min}$ and the pellet was washed five times with HNTG buffer $(20 \mathrm{mM}$ Hepes, $\mathrm{pH}$ $7 \cdot 5,150 \mathrm{mM} \mathrm{NaCl}, 10 \%$ glycerol and $0 \cdot 1 \%$ Triton $\mathrm{X}-100)$. Pit-1 and GH were then resuspended in $2 \times$ SDS sample buffer (50 mM Tris-HCl, pH 6.8, 2\% SDS, 2\% b-mercaptoethanol and bromophenol blue) and boiled for $5 \mathrm{~min}$. The samples were subjected to $12 \%$ or $15 \%$ SDS-PAGE electrophoresis (for Pit-1 and GH respectively). Proteins were transferred for $2 \mathrm{~h}$ at $4{ }^{\circ} \mathrm{C}$ to nitrocellulose membranes. Nitrocellulose membranes were blocked with $0 \cdot 1 \mathrm{~g}$ casein in PBS with $0 \cdot 1 \%$ Tween 20 (PBST) for $1 \mathrm{~h}$ at room temperature. Blots were then immunolabeled overnight at $4{ }^{\circ} \mathrm{C}$ with: (1) polyclonal anti-Pit-1 antiserum (Santa Cruz Biotechnology, Santa Cruz, CA, USA) and (2) polyclonal anti-hGH antibody (a kind gift from Dr A F Parlow, NIDDK, Bethesda, MD, USA). After five washes for 5 min each in washing buffer (PBST), membranes were incubated with goat anti-rabbit IgG (1:5000) alkaline-phosphatase-conjugated second antibody, using $\mathrm{CSPD}^{\circledR}$ as substrate (Tropix, PE Biosystem, Bedford, MA, USA) for $1 \mathrm{~h}$ at room temperature. The membranes were further washed five times for $5 \mathrm{~min}$ each time in PBST before immunolabeling. Immunolabeling was detected by placing the blot with standard X-ray film according to the manufacturer's instructions (Tropix).

\section{Immunohistochemistry}

One hundred microliters of MCF-7 cells in suspension were put on autoclaved 3-aminopropyl-triethoxysilanecoated slides at $37{ }^{\circ} \mathrm{C}$ for $30 \mathrm{~min}$. Slides were placed in Petri dishes with DMEM overnight at $37^{\circ} \mathrm{C}$. The medium was then removed and the slides were air dried. After that, MCF-7 cells were fixed by the following procedure: $15 \mathrm{~min}$ in $10 \%$ buffered formalin, $5 \mathrm{~min}$ in PBS (0.01 mol/1 phosphate buffer, $\mathrm{pH} 7 \cdot 4$, containing $0.15 \mathrm{~mol} / 1 \mathrm{NaCl}), 4 \mathrm{~min}$ in $-20^{\circ} \mathrm{C}$ methanol, $2 \mathrm{~min}$ in $-20{ }^{\circ} \mathrm{C}$ acetone and 5 min twice in PBS. Pit-1 (X-7) affinity-purified rabbit polyclonal antibody (Santa Cruz Biotechnology, Inc.; raised against a polyhistidine fusion protein construct containing sequences corresponding to full length Pit-1 of rat origin) or polyclonal antibody to GH (Dakopatts, Glostrup, Denmark) were used. The antigens were retrieved by microwaving at $750 \mathrm{~W}$ for $10 \mathrm{~min}$ in $0.01 \mathrm{M}$ trisodium citrate buffer, $\mathrm{pH} 6 \cdot 0$. The streptavidin-biotin complex (SABC) immunohistochemical method was used and the sections were consecutively incubated in: (1) 3\% hydrogen peroxide (Merck, Darmstadt, Germany) in distilled water for $10 \mathrm{~min}$ in order to block endogenous peroxidase; (2) polyclonal antibody anti-Pit-1 at a dilution of $1 / 10$ for $1 \mathrm{~h}$ at room temperature or polyclonal antibody to $\mathrm{GH}$ at a dilution of $1 / 100$ for $1 \mathrm{~h}$ at room temperature; (3) biotinylated goat antibodies to mouse/rabbit immunoglobulins (Duet kit; Dakopatts) at a dilution of $1 / 100$, for $30 \mathrm{~min}$; (4) streptavidinbiotin-peroxidase complex (Duet kit: Dakopatts) prepared according to the protocol provided by the manufacturer, for $30 \mathrm{~min}$; and (5) 3,3'-diaminobenzidine-tetrahydrochloride (DAB) solution prepared by dissolving one DAB buffer tablet (Merck) in $10 \mathrm{ml}$ distilled water for $10 \mathrm{~min}$. Between steps, the sections were washed twice for 5 min with PBS and after step 5 with distilled water. All dilutions were made in PBS. This buffer was added with $0 \cdot 1 \%$ bovine serum albumin (Sigma Chemical Co.) for dilution of the primary antibodies (step 2) and with 1.5\% normal goat serum (Dakopatts) for the biotinylated antibodies (step 3). No counterstaining was carried out.

To avoid the use of streptavidin (and then to be sure that we were not revealing endogenous biotin), the 
A

B

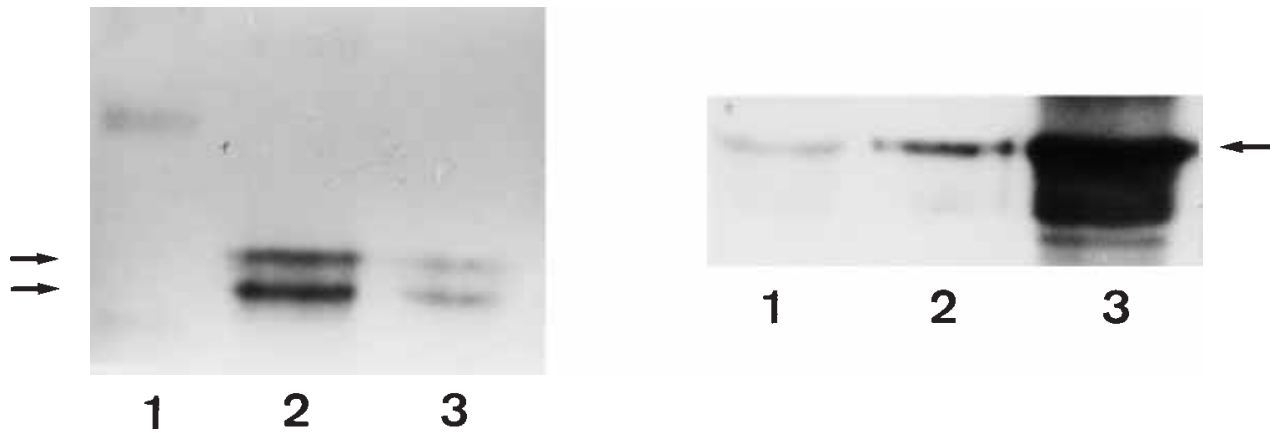

Figure 2 Western blot analysis of immunoreactive Pit-1 and GH in MCF-7 cell line. Cell extracts obtained from the MCF-7 cell line were prepared and subjected to SDS-PAGE, and Western blot analyses were performed as described in Materials and Methods. (A) The blot was incubated with the polyclonal Pit-1 antiserum. The major 31 and $33 \mathrm{kDa}$ immunoreactive bands are indicated by arrows. Lane 1: molecular weight marker (10-200 kDa prestained protein ladder). Lane 2: human pituitary extract used as control. Lane 3: MCF-7 cell line extract. (B) The blot was incubated with the polyclonal GH antiserum. The immunoreactive GH band is indicated by an arrow. Lane 1: MCF-7 cell line extract. Lane 2: human recombinant $\mathrm{GH}$ used as control. Lane 3: human pituitary extract also used as control.

immunohistochemical detection of GH was also automatically performed (TechMate 500; Dako Carpinteria, CA, USA) using the Dako EnVision staining procedure that substitutes steps 3 and 4 with goat anti-rabbit immunoglobulins conjugated to peroxidase-labeled dextran polymer (30 min).

Controls for specificity of immunohistochemistry included using alternately PBS in place of one of the incubation steps or incubation with the primary antibodies preadsorbed overnight at $4{ }^{\circ} \mathrm{C}$ with the immunogen peptides Pit-1 (Santa Cruz) and GH (Pharmacia Iberia, San Cugat del Vallés, Spain).

\section{Results}

Detection of Pit-1 and GH mRNA by RT-PCR

PCR amplification of cDNA prepared from MCF-7 human adenocarcinoma cells gave rise to a $295 \mathrm{bp}$ PCR product corresponding to human Pit-1 (33 kDa) (Fig. 1A, lane 3) and a $344 \mathrm{bp} \mathrm{PCR} \mathrm{product} \mathrm{corresponding} \mathrm{to} \mathrm{hGH}$ (Fig. 1B, lane 3). In order to verify the identity of PCR products, we performed restriction enzyme cleavage. PCR products have a characteristic and unique restriction site localized between the primers. The restriction enzymes used were Mbo II for Pit-1 and Bgl II for GH product. Mbo II cleaves the product at position 405 (corresponding to the Pit-1 cDNA) obtaining $219 \mathrm{bp}$ and $76 \mathrm{bp}$ fragments. Bgl II cleaves the PCR product at position 551 (corresponding to the hGH cDNA) obtaining $237 \mathrm{bp}$ and $107 \mathrm{bp}$ fragments. These patterns were visualized on ethidium bromide staining of $2 \%$ NuSieve (BMA, Rockland, ME, USA) agarose gel electrophoresis (Fig. 1A, lane 4 and $\mathrm{B}$, lane 4). The PCR products were also sequenced to confirm the identity of Pit-1 and GH cDNAs using the fmol DNA cycle sequencing system from Promega. The sequences were identical to the pituitary Pit-1 and GH (data not shown).

\section{Detection of Pit-1 and GH protein by Western blotting}

Two major Pit-1 immunoreactive bands were readily visible with the MCF-7 extracts (Fig. 2A, lane 3). These bands, which arise from alternative translation initiation codon usage of Pit-1 mRNA, have been referred to previously as 31 and $33 \mathrm{kDa}$ (Voss et al. 1991). Western blots also clearly showed similar immunoreactive bands from human pituitary gland extracts used as control (Fig. 2A, lane 2).

GH was also detectable in MCF-7 cells by Western blotting. The results of anti-hGH-antibody binding revealed a $22 \mathrm{kDa}$ protein band corresponding to the approximate molecular weight of hGH protein (Fig. 2B, lane 1). We also observed a strong band corresponding to the recombinant $\mathrm{GH}$ (Fig. 2B, lane 2) and the human pituitary gland extracts (Fig. 2B, lane 3) used as positive controls.

We also performed Western blots for Pit-1 and GH protein detection using Saos-2 (human osteosarcoma cell line) and Hek-293 (human embryo kidney cell line), but were unable to find any meaningful expression of either of them (data not shown).

\section{Detection of Pit-1 and GH by immunohistochemistry}

MCF-7 cells showed positivity for Pit-1. Immunoreactivity appeared as a punctate signal identified in the nuclei of 
MCF-7 cells (Fig. 3a). No immunoreactivity was observed when the primary antibody was preadsorbed with the homologous antigen (Fig. 3b).

Immunostaining for $\mathrm{GH}$ was localized in the cytoplasm of MCF-7 cells. Both methods, SABC and EnVision, showed a weak positivity in MCF-7 (Fig. 3c and d). No
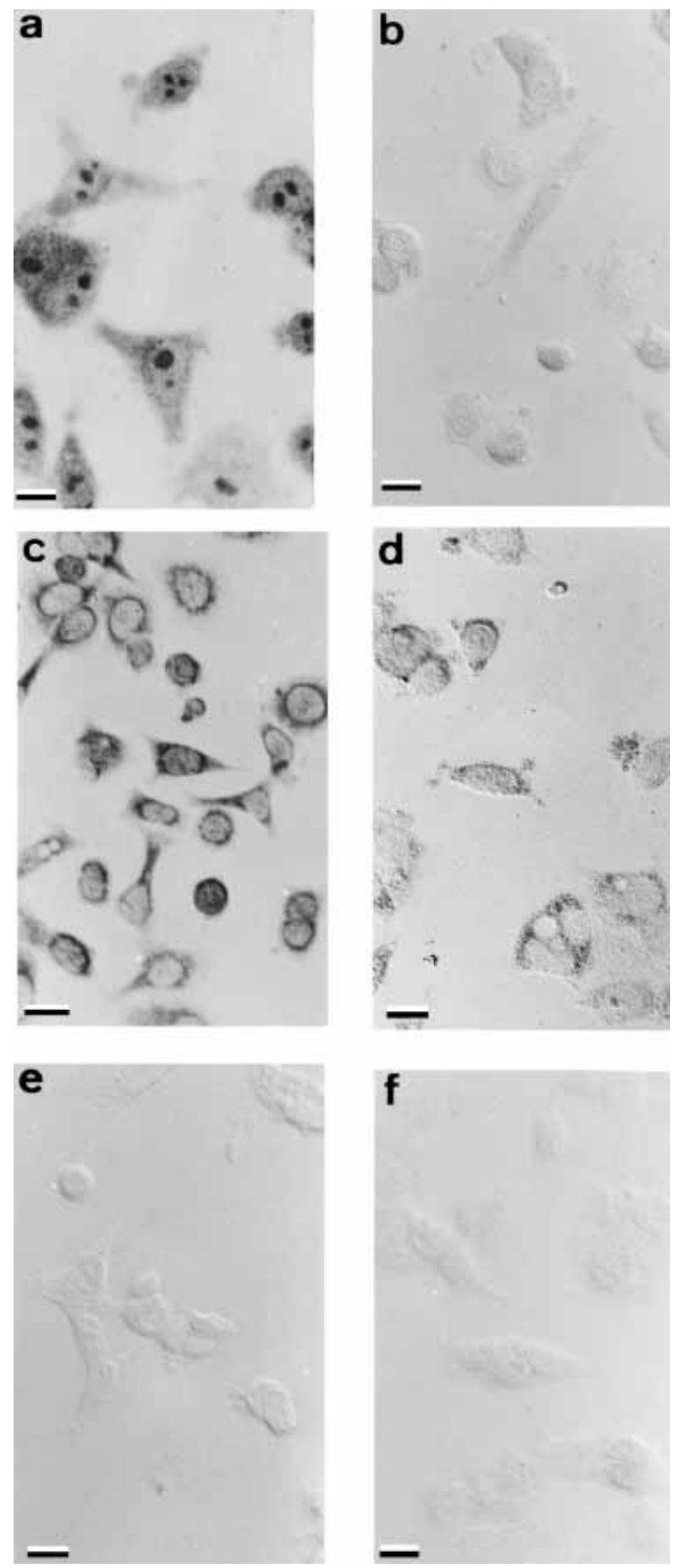

immunoreactivity was observed when the primary antibody or other incubation steps were substituted by PBS (Fig. 3e) or when the primary antibody was preadsorbed with the homologous antigen (Fig. 3f).

\section{Discussion}

The presence of Pit-1 synthesis in the pituitary is required for prolactin, GH and TSH cell commitment, differentiation and gene expression (Karin et al. 1990, Simmons et al. 1990, Steinfelder et al. 1991). Indeed, the inhibition of Pit-1/GHF-1 synthesis leads to a marked decrease in cell proliferation in $\mathrm{GH}$ - and prolactin-producing cell lines (Castrillo et al. 1991). The expression of Pit-1 was higher in pituitary adenomas than in normal pituitary, and this expression is restricted to $\mathrm{GH}-$, prolactin- and TSHexpressing cells, suggesting a possible role of this transcription factor in the pathogenesis of pituitary tumors (Asa et al. 1993, Delhase et al. 1993b). In non-pituitary tissues, Lantinga-van Leeuwen et al. (1999) did not find Pit-1 expression either in normal or progestin-induced GH expressing canine mammary gland, suggesting that $\mathrm{GH}$ gene expression appears to be independent of Pit-1 at least before malignant mammary transformation. In the human myeloid leukemic HL-60 cells, the presence of Pit-1 has been demonstrated, and this presence is correlated with their degree of proliferation but appears to be independent of cell differentiation (Costoya et al. 1998).

In our work, we have demonstrated the presence of mRNA coding Pit-1 (using RT-PCR) and Pit-1 protein (both using Western blot and immunochemistry) in MCF-7 human breast adenocarcinoma cells. Thus, these data demonstrated that Pit-1 is expressed in a tumoral cell line, supporting the hypothesis that Pit-1, as in canine mammary tumors or in HL-60 cells, could be related to an increased proliferation process.

The role of GH as well as the factors involved in their control in the pituitary gland is well established. However, the role of $\mathrm{GH}$ production in extra-pituitary tissues and the mechanisms that control this expression are currently

Figure 3 Immunohistochemical detection of Pit-1 and $\mathrm{GH}$ in MCF-7 cell line. (a) MCF-7 cells immunostained for Pit-1. A granular signal is shown in the nuclei (objective magnification $\times 60$ ). (b) Negative control for Pit- 1 . No signal was detected when the antiserum was preadsorbed with the homologous antigen (Nomarsky differential interference contrast; objective magnification $\times 40$ ). (c) MCF-7 cells immunostained for $\mathrm{GH}$ by the SABC method. A weak positivity was detected in the cytoplasm (objective magnification $\times 40$ ). (d) MCF-7 cells immunostained for $\mathrm{GH}$ by the EnVision method. A weak positivity is also observed (objective magnification $\times 40$ ). (e) Negative control for $\mathrm{GH}$ performed by substitution of $\mathrm{GH}$ polyclonal antibody with PBS (objective magnification $\times 40$ ). (f) Negative control for GH. No signal was found when the antiserum was preadsorbed with the homologous antigen (Nomarsky differential interference contrast; objective magnification $\times 40$ ) Bars: $20 \mu \mathrm{m}$. 
under discussion. $\mathrm{GH}$ and $\mathrm{GH}$ receptors are present in the human mammary gland (Decouvelaere et al. 1995, Mol et al. 1995a). Endocrine and autocrine GH exert a direct effect on the development and differentiation of mammary epithelia in vitro and in vivo (Feldman et al. 1993, Plaut et al. 1993) and elevated GH levels in sera have been correlated with breast cancer (Emerman et al. 1985). In a recent paper it has been demonstrated that treatment with $\mathrm{GH}$ induces mammary gland hyperplasia in aging primates ( $\mathrm{Ng}$ et al. 1997), suggesting that this mammary epithelial proliferation may be a consequence of the increased levels of IGF-I induced by the high levels of GH or directly by acting through the epithelial prolactin receptor. The latter hypothesis has also been discussed in a recent paper (Wennbo \& Törnell 2000).

On the other hand, it has been demonstrated that hGH can act in an autocrine manner in MCF-7 cells to promote cell proliferation and transcriptional activation, and that the increase of $\mathrm{GH}$ production enhances the rate of mammary carcinoma cell spreading in a JAK2-dependent manner (Kaulsay et al. 1999, 2000). Interestingly, these researchers demonstrated that the autocrine-produced $\mathrm{hGH}$ is a more potent stimulator of mammary carcinoma cell spreading than exogenously administered $\mathrm{hGH}$, and this effect is mediated via the hGH receptor (Kaulsay et al. 2000, 2001). However, in these above-mentioned works the authors used a model system in which the hGH gene or a translation-deficient hGH gene (as negative control) is stably transfected into MCF-7 cells. The fact that, for the first time, we have demonstrated the presence of hGH in MCF-7 cells could be due to the transformation of these malignant cells. In any event, we think that the presence of hGH should be tested when using these MCF-7 cells to evaluate the effects of $\mathrm{GH}$ on tumor mammary proliferation or spreading.

Thus, in this work, we have demonstrated the presence of both Pit-1 and GH in the MCF-7 human breast adenocarcinoma cell line. The presence of GH, the main regulator of Pit-1 in the pituitary, in this MCF-7 cell line provides a model that should be carefully studied to see the effects of both Pit-1 and/or GH on the development, maintenance or spread of breast tumors. Although from our data we cannot demonstrate that Pit-1 regulates mammary GH expression, the presence of both Pit-1 and GH mRNA and protein together with the GH receptor in breast tumor cell line MCF-7 could be related to Pit-1 acting directly or co-ordinately with $\mathrm{GH}$ on cell proliferation. Further studies assessing this hypothesis are clearly merited.

\section{Acknowledgements}

We are grateful to Celsa Quinteiro for sequencing Pit-1 and GH PCR products, Maria Pardo and Angel García for helping us in the Western blots and Carlos Diéguez for critical evaluation of the manuscript. This work was supported by a Xunta de Galicia grant (PGIDT00 PXI20806PR) and grant (PGIDT99PX120806B). M B is a recipient of a studentship from the Deputación de A Coruña.

\section{References}

Asa SL, Puy LA, Lew AM, Sundmark VC \& Elsholtz HP 1993 Cell type-specific expression of the pituitary transcription activator Pit-1 in the human pituitary and pituitary adenomas. Journal of Clinical Endocrinology and Metabolism 77 1275-1280.

Bamberger AM, Bamberger CM, Pu LP, Puy LA, Loh YP \& Asa SL 1995 Expression of Pit-1 messenger ribonucleic acid and protein in the human placenta. Journal of Clinical Endocrinology and Metabolism $802021-2026$.

Bodner M, Castrillo JL, Theill LE, Deerink T, Ellisman M \& Karin M 1988 The pituitary specific transcription factor GHF-1 is a homeobox-containing protein. Cell 50 505-518.

Castrillo JL, Theill L \& Karin M 1991 Function of the homeodomain protein GHF1 in pituitary cell proliferation. Science 253 197-199.

Chen R, Ingraham HA, Treacy MN, Albert VR, Wilson L \& Rosenfeld MG 1990 Autoregulation of Pit-1 gene expression is mediated by two cis-active elements. Nature 346 583-586.

Costoya JA, García-Barros M, Gallego R, Señarís R, Arce VM \& Devesa J 1998 Correlation of Pit-1 gene expression and Pit-1 content with proliferation and differentiation in human myeloid leukemic cells. Experimental Cell Research 245 132-136.

Decouvelaere C, Peyrat J-P, Bonneterre J, Djiane J \& Jammes H 1995 Presence of two growth hormone receptor messenger RNA isoforms in human breast cancer. Cell Growth and Differentiation 6 477-483.

Delhase M, Vergani P, Malur A, Hooghe-Peters EL \& Hooghe RJ 1993a The transcription factor Pit-1/GHF-1 is expressed in hemopoietic and lymphoid tissues. European Journal of Immunology 23 951-955.

Delhase M, Vergani P, Malur A, Velkeniers B, Tengels E, Trouillas J \& Hooghe-Peters EL 1993b Pit-1/GHF-1 expression in pituitary adenomas: further analogy between human adenomas and rat SMtTW tumours. Journal of Molecular Endocrinology 11 129-139.

Dollé P, Castrillo JL, Theill LE, Deerinck T, Ellisman M \& Karin M 1990 Expression of GHF-1 protein in mouse pituitaries correlates both temporally and spatially with the onset of growth hormone gene activity. Cell 60 809-820.

Emerman JT, Leahy M, Gout PW \& Bruchovsky N 1985 Elevated growth hormone levels in sera from breast cancer patients. Hormone and Metabolic Research 17 421-424.

Feldman M, Ruan W, Cunningham BC, Wells JA \& Kleinberg DL 1993 Evidence that the growth hormone receptor mediates differentiation and development of the mammary gland. Endocrinology 13 1602-1608.

Ingraham HA, Chen R, Mangalam HJ, Elsholtz HP, Flynn SE, Lin CR, Simmons DM, Swanson L \& Rosenfeld MG 1988 A tissuespecific transcription factor containing a homeodomain specifies a pituitary phenotype. Cell 55 519-529.

Karin M, Castrillo JL \& Theill LE 1990 Growth hormone gene regulation: a paradigm for cell-type-specific gene activation. Trends in Genetics 6 92-96.

Kaulsay KK, Mertani HC, Törnell J, Morel G, Lee K-O \& Lobie P 1999 Autocrine stimulation of human mammary carcinoma cell proliferation by human growth hormone. Experimental Cell Research $25035-50$

Kaulsay K, Mertani HC, Lee K-O \& Lobie P 2000 Autocrine human growth hormone enhancement of human mammary carcinoma cell spreading is Jak2 dependent. Endocrinology 141 1571-1584. 
Kaulsay KK, Zhu T, Bennet W, Lee K-O \& Lobie P 2001 The effects of autocrine human growth hormone (hGH) on human mammary carcinoma cell behavior are mediated via the $\mathrm{hGH}$ receptor. Endocrinology 142 767-777.

Lantinga-van Leeuwen IS, Oudshoorn M \& Mol JA 1999 Canine mammary growth hormone gene transcription initiates at the pituitary-specific start site in the absence of Pit-1. Molecular and Cellular Endocrinology 150 121-128.

Lefevre C, Imagawa M, Dana S, Grindlay J, Bodner M \& Karin M 1987 Tissue specific expression of the human growth hormone gene is conferred in part by the binding of a specific trans-acting factor. EMBO Journal 6 971-981.

Li S, Crenshaw EB, Rawson EJ, Simmons DM, Swanson LW \& Rosenfeld MG 1990 Dwarf locus mutants lacking three pituitary cell types result from mutations in the POU-domain gene Pit-1. Nature 347 528-533.

Lin C, Lin SC, Chang CP \& Rosenfeld M 1992 Pit-1-dependent expression of the receptor for growth hormone releasing factor mediates pituitary cell growth. Nature 360 765-768.

Lin S-C, Li S, Drolet DW \& Rosenfeld MG 1994 Pituitary ontogeny of the Snell dwarf mouse reveals Pit-1-independent and Pit-1-dependent origins of the thyrotrope. Development 120 515-522.

McCormick A, Brady H, Theill LE \& Karin M 1990 Regulation of the pituitary specific homeobox gene GHF-1 by cell autonomous and environmental cues. Nature 345 829-832.

Mertani HC, Garcia-Caballero T, Lambert A, Gerard F, Palayer C, Boutin JM, Vonderhaar BK, Waters MJ, Lobie PE \& Morel G 1998 Cellular expression of growth hormone and prolactin receptors in human breast disorders. International Journal of Cancer 79 202-211.

Mol JA, Henzen-Logmans SC, Hageman P, Misdorp W, Blankenstein MA \& Rijnberk A 1995a Expression of the gene encoding growth hormone in the human mammary gland. Journal of Clinical Endocrinology and Metabolism 80 3094-3096.

Mol JA, van Garderen E, Seiman PJ, Wolfswinkel J, Rijnberk A \& Rutteman GR 1995b Growth hormone mRNA in mammary gland tumors of dogs and cats. Journal of Clinical Investigation $\mathbf{9 5}$ 2028-2034

Nelson C, Albert VR, Elsholtz HP, Lu LI-W \& Rosenfeld MG 1988 Activation of cell-specific expression of rat growth hormone and prolactin genes by a common transcription factor. Science $\mathbf{2 3 9}$ $1400-1405$.

Ng ST, Zhou J, Adesanya OO, Wang J, LeRoith D \& Bondy C 1997 Growth hormone treatment induces mammary gland hyperplasia in aging primates. Nature Medicine 3 1141-1144.

Peyrat JP, Bonneterre J, Hecquet B, Vennin P, Louchez MM, Fournier C, Lefebvre J \& Demaille A 1993 Plasma insulin-like growth factor-1 (IGF-1) concentrations in human breast cancer. European Journal of Cancer 29A 492-497.

Plaut K, Ikeda M \& Vonderhaar BK 1993 Role of growth hormone and insulin-like growth factor-1 in mammary development. Endocrinology 133 1843-1848.

Rosenfeld MG 1991 POU-domain transcription factors: powerful developmental regulators. Genes and Development 5 897-907.

Schanke JT, Conwell CM, Durning M, Fisher JM \& Golos TG 1997 Pit-1/growth hormone factor 1 splice variant expression in the rhesus monkey pituitary gland and the rhesus and human placenta. Journal of Clinical Endocrinology and Metabolism 82 800-807.

Simmons DM, Voss JW, Ingraham HA, Holloway JM, Broide RS, Rosenfeld MG \& Swanson LW 1990 Pituitary cell phenotypes involve cell-specific Pit-1 mRNA translation and synergistic interactions with other classes of transcription factors. Genes and Development 4 695-711.

Sobrier ML, Duquesnoy P, Duriez B, Amselem S \& Goossens M 1993 Expression and binding properties of two isoforms of the human growth hormone receptor. FEBS Letters 319 16-20.

Steinfelder HJ, Hauser P, Nakayama Y, Radovick S, McClaskey JH, Taylor T, Weintraub BD \& Wondisford FE 1991 Thyrotropinreleasing hormone regulation of human TSHB expression: role of a pituitary-specific transcription factor (Pit-1/GHF-1) and potential interaction with a thyroid hormone-inhibitory element. PNAS $\mathbf{8 8}$ 3130-3134.

Voss JW, Yao T-P \& Rosenfeld MG 1991 Alternative translation initiation site usage results in two structurally distinct forms of Pit-1. Journal of Biological Chemistry 266 12832-12835.

Wennbo H \& Törnell J 2000 The role of prolactin and growth hormone in breast cancer. Oncogene 19 1071-1076.

Received 7 December 2001

Accepted 19 December 2001 